The Geneva Papers on Risk and Insurance, 20 (No. 77, October 1995) 474-480

\title{
Catastrophe Insurance System in France
}

\author{
by Serge Magnan*
}

\section{Introduction}

Since the beginning of the fifties, French insurance companies have guaranteed damage caused by storms and hail on roofs.

In 1981, companies began to guarantee damage caused by the weight of snow on roofs, as well as damage caused by earthquakes, but only for industrial risks.

However, French insurance companies refused to cover damage caused by other natural disasters. Regarding earthquake damage affecting personal property, no satisfactory solution was found with reinsurers because of considerable insurance indemnities which might have been generated by a hypothetical earthquake in south-east France. An earthquake destroying the city of Nice would lead to damages anywhere from 10 to 20 billion dollars ( 50 to 100 billion francs).

No solution was found for flood insurance since only property located near rivers would have purchased this type of insurance, resulting in very high premiums, economically unbearable for policyholders.

To illustrate this point, let's take the example of a building damaged every 20 years because of flood ( $5 \%$ frequency), with an average extension rate of $10 \%$. The pure premium would be $5 \% \times 10 \%=50 \%$. In the case of an individual house with a face value of 200,000 dollars ( 1 million francs), the pure premium would be $\$ 200,000 \times 5 \%=\$ 1,000$. After including a $33.33 \%$ expense rate, the premium would be $\$ 1,500$ (7,500 FRF), considered as excessive and inadequate for policyholders.

Following the serious flooding which occurred at the end of 1981, particularly in the Saône valley, the French Parliament voted a law, issued July 13, 1982, which instituted a new compensation system for natural disasters, for damages occurring from August 14, 1982 onwards.

Succinctly, the system can be defined as follows:

Insurance contracts guaranteeing fire and other damage to property located in France, damage to motor vehicles and losses of business profits, are considered also guaranteeing the policy-holder against direct material damage and losses of profits caused by a natural disaster. A state of natural disaster is declared by ministerial decree.

\footnotetext{
* Managing Director APSAD/FFSA, Paris.
} 
This guarantee is financed by an additional premium calculated on the basis of a single rate set by decree for each line of business. However, considering the scope of risk characterized by these hazards, the system is balanced by the Central Re-insurance Company (Caisse Centrale de Réassurance) which intervenes under Government guarantee.

\section{Events guaranteed}

Legislation defines a natural disaster as an event resulting from the abnormal intensity of a natural agent. In practice, this is flooding, landslides and subsidence, drought, avalanches, earthquakes and tidal waves.

In principle, the new system was not supposed to include storms, hurricanes, cyclones and hail on roofs since they were widely guaranteed before August 14, 1982.

The exceptional force of the storms which occurred from November 6 to 10, 1982 and during June, July and August 1983 led the Public Authorities to exceptionally consider that these events constituted a natural disaster. The fact that a significant number of victims were not covered against this hazard also influenced the Government decision. Insurance companies were invited by the Authorities to engage a systematic insurance campaign before December 31, 1983 since storms, hail and the weight of snow on roofs would no longer be considered natural disasters beginning on January 1, 1984 by the law of July 13, 1982.

The storm of October 15, 1987, which raged over Brittany, was nonetheless termed a natural disaster.

The law of June 25, 1990 (article L 122-7 of the French Insurance Code) provided a definitive solution to this problem. It provides that "Insurance policies guaranteeing fire damage - or losses of profits following a fire - to property located in France provide the policy-holder with a guarantee against the effects of wind due to storms, hurricanes or cyclones on the property covered by such policies". This law also included French overseas departments and territories in the "natural disaster system".

Finally, the law of July 16, 1992 specified that material damage not insured in the past would henceforth be considered as the effects of natural disasters. The preamble to the bill stipulated that damage caused by storms, hail, the weight of snow and frost will be insured.

\section{Event declared by ministerial decree}

A disaster victim cannot automatically receive compensation for damaged property unless the event has been declared as a natural disaster by Inter-Ministerial Decree (made by the Minister of the Interior, the Minister of the Economy and Finances and the Budget Minister).

This obligation of declaration by Ministerial Decree helps contain compensation requests. The concerned ministries estimate that this phenomenon does not correspond to the spirit of the new compensation system $(25 \%$ of the reports filed with the inter-ministerial commission are rejected).

An inter-ministerial decree can also be used by the Public Authorities to delimit the respective areas of contractual guarantees and compulsory insurance for natural disasters.

The example of storms clearly illustrates the role played by a decree in this respect. 


\section{Property guaranteed}

Real estate property and movables ("including motor vehicles") which are insured against fire damage or all other damages are guaranteed. As a consequence of a property insurance completed with a disaster insurance, properties such as land, cultivation, roads, etc., which are not generally insured against fire or another form of damage are excluded from the compensation system. Same thing for properties which are excluded from insurance policies against damage, fences for instance.

Properties covered are those belonging to individuals or companies other than the State.

Furthermore, the law explicitly excludes damage caused to non-stored harvest, livestock outside buildings, cultivation and soils which are covered by a special system guaranteeing agricultural calamities.

Damage to aircraft, commercial or private boats, as well as the goods transported are also excluded from the scope of application of the law. Conventional insurance contracts guaranteeing these items generally extend coverage to include all natural events.

\section{The nature of damage guaranteed}

Only direct material damage which, as defined in standard provisions, "affect the structure or the substance of the thing" are covered.

Expenses and losses, such as indirect losses, losses of rent, losses of utilization, reimbursement of inspection fees, etc. are not covered.

Furthermore, material damage must be direct. Damage incurred by electrical equipment or freezers contents are not covered when the damage results from a power outage caused by a natural disaster.

Furthermore, the law provides that if the policy-holder is covered against losses of profits, this guarantee is extended to natural disasters effects per the terms of the contract.

The guarantee of profits losses is possible only when the natural disaster has affected the company's property. Whatever the provisions of the policy, losses such as those arising from supplier default, inaccessibility or environmental liability are not covered.

\section{Disaster settlement - scope of guarantee}

\subsection{Compensation basis}

Disasters affecting homes, industrial or commercial risks are compensated on the basis of the main contract guarantee, which is generally fire insurance for comprehensive policies which are most often concerned since the most numerous.

\subsection{Obsolescence}

Damages are compensated per the "deducted obsolescence" value (with a deduction for wear and tear) or per "new value" if the extended "new value" guarantee was taken out.

\subsection{Average clause}

Damages are compensated within the limit of the capital provided for in the contract. If necessary, contractual limits, first losses, and average clause will be applied if the guaranty is insufficient. 
If the policy-holder fails to answer the questionnaire used to set up the policy, or files an erroneous one and this has an influence on the additional natural disaster premium, a premium average clause can be applied.

\subsection{Excess}

The excess applicable for motor vehicles, homes and other properties for non-professional use is still 300 dollars (1500 francs) whatever the contract provisions regarding "damage" guarantees.

The excess applicable to property for professional use, which includes property belonging to local authorities, is equal to $10 \%$ of the amount of direct damage with a minimum of 900 dollars (4500 francs). However, when a higher excess is provided for in the contract for the basic risk, the latter is the one applied.

The excess applicable for losses of profits is 3 working days with a minimum of 900 dollars (4500 francs) except if a higher excess is provided for in the basic contract.

The insurance company cannot modify the excesses thus set. Furthermore, the policyholder cannot take out insurance covering the part of the risk included in the excess.

\subsection{Claim report}

In case of disaster, the policy-holder must file the claim report no later than ten days after the publication of the inter-ministerial decree for material damage and no later than 30 days for profit losses.

\subsection{Insurance compensation payment}

The insurance company must pay the compensation within three months beginning on the date the policy-holder turned over the damaged property or loss estimate. When the decree publication date falls after the date the estimate was filed, this publication shall constitute the beginning of the three month period.

If payment is not made within this three month period, claims payment shall bear interest at the legal rate unless the insurance company proves the delay corresponds to an extreme case.

\subsection{Standard clauses}

Standard clauses deemed written in the contracts beginning August 14, 1982 were published by decree.

In practice, most insurance companies simply reproduced these clauses in a special form attached to the policy.

\section{Additional premium}

The law provides for an additional premium which must be personalized in the payment notice and which is calculated on the basis of a single rate set by decree for each category of policy.

The additional premium applies to all premiums relating to damage contracts. It can apply to the same item several times when that item is guaranteed by several types of damage insurance (fire, theft, water damage, etc.). This is the price insurance must pay for the notion of solidarity. 


\subsection{Premium rate}

From August 1982 to October 1983, premium rates were, for automobile insurance, $9 \%$ of the theft and fire premium, or $0,80 \%$ of the damage guarantee premium and $5,5 \%$ for the branches covering fire and other damages to property as well as loss of profit guarantees.

The 5,5\% rate set in 1982 by the Public Authorities for insurance branches other than automobile took into consideration a damage load assignable to flooding in an average year of about 120 million dollars ( 600 million francs). The results expected from this rate were slightly over 200 million dollars ( 1 billion francs) and should, in principle, have allowed the compensation of damage from "flooding", the most frequent disaster, and damage from some other natural disasters less costly on an average year: avalanches, landslides, etc. as well as covering the overhead of the insurance companies and the commissions of intermediaries.

During the system's first year of operation (August 14, 1982/December 31, 1983) damage assignable to natural disasters reached over 600 million dollars ( 3 billion francs).

The damage level for this period was exceptional. Furthermore, during this period, the system covered storms, which were not included when the 5,5\% rate was established.

The $5,5 \%$ rate was increased to $9 \%$ on October 1,1983 .

Beginning on January 1, 1986 the rates for automobile insurance premiums went to $6 \%$ of the theft and fire premium or $0,50 \%$ of the damage guarantee premium.

The $9 \%$ rate was not modified for other P\&C lines of insurance. Until today, the rate has not permitted the insurance companies to constitute all the equalization reserves allowed by the law.

The reserves constituted by insurance companies amounted 340 million dollars $(1,7$ billion francs) on December 31, 1994. Reserves of the Central Reinsurance Company (Caisse Centrale de Réassurance) amounted for 520 million dollars (2,6 billion francs).

\subsection{Equalization reserves}

Premiums can be used to constitute a tax-free equalization reserve.

The annual reserve allocation is limited to $75 \%$ of technical profit of the risk category concerned.

The overall amount of this reserve cannot exceed $300 \%$ of the amount of premiums or subscriptions, minus cancellations and reinsurance, issued during the fiscal year.

Annual allocations which, within ten years, have not been used as per this objective are included in the taxable profit of the eleventh year following their accounting entry.

\section{Intermediary commissions}

A December 2, 1983 decree limits the commissions of intermediaries regarding the insurance of natural disasters to $8 \%$. Additional remuneration per claim file settled can be added to this rate.

\section{Reinsurance}

Considering the scope of the risk involved with natural disasters, insurance companies would have been unable to find any protection on the world reinsurance market. 
Legislation thus authorized the Central Reinsurance Company (Caisse Centrale de Réassurance-CCR), a public commercial establishment, to underwrite these risks with a guarantee from the State.

This is not a compulsory system, insurance companies may or may not opt for reinsurance and they may choose their reinsurer.

Practically all insurance companies operating in France are reinsured at the CCR. CCR offers to companies a proportional treaty completed by an excess of loss treaty.

The range of companies cession rates are between $40 \%$ to $90 \%$; average rate of market cession is $43 \%$.

On their retention, companies are protected by a stop loss clause from loss ratios (losses over premium) of $120 \%, 135 \%, 150 \%, 175 \%$ or $200 \%$ depending on their own choice. Treaties also contain a clause of technical excess repartition.

\subsection{Prevention}

The law distinguishes two periods. During the first period, going from August 14, 1982 to the day the "prevention natural risk exposure plans" are implemented, insurance companies can refuse coverage only for items built in violation of administrative rules in effect at the time of their construction or creation and only with contract renewal or termination. On the other hand, they cannot refuse to cover risks already insured. Here the lawmaker aimed for the compensation of damage victims who had paid their additional premium.

The second period begins after the publication of the natural risks exposure plans (which would soon become "natural risk prevention plans").

When the plans are drafted, the insurance company can refuse to extend the "natural disaster" guarantee to buildings built in high-risk zones. Preventive measures must be taken within five years for those built in medium-risk zones; in other cases, a ratemaking bureau will apply to company strict guaranty conditions.

Finally, the law provides that policy-holders who have been unsuccessful in obtaining natural disaster insurance from at least three different insurance companies may contact a pricing bureau. The bureau is allowed to exclude certain items from the guarantee and apply increased excesses. This bureau can require that the insurance company chosen by the policy-holder grants the "natural disaster" guarantee.

\section{Results of the compensation system}

During the system's first year of application, which was rife with disasters, 92 of the 95 French Counties were covered by one or more inter-ministerial decrees.

For the period from August 14, 1982 to December 31, 1983, premiums reached 500 million dollars (2,5 billion French francs) while disaster damages totalled 660 million dollars (3,3 billion French francs).

In 1984, disasters were much less frequent and during this period the system did not cover storm damage.

The years 1985 and 1986 were also favorable. Results for 1987 were affected by the coverage of part of the damage of the October 15th storm, but remained favorable over all. 
In 1988 the Nimes disaster occurred ( 400 million dollars or 2 billion francs in damage). Drought predominated for the next three years 1989, 1990 and 1991 (over three billion francs in damage), and in 1992 the flooding at Vaison-la-Romaine and in the south-east caused 320 million dollars (1,6 billion francs) in damage. Flooding in the north, south and west in 1993 engendered 800 million dollars (4 billion francs) in damage.

In 1994, catastrophe losses for flood totalled 400 million dollars ( 2 billion francs). For the first three months of 1995 , flood losses represented 540 million dollars $(2,7$ billion francs).

Nevertheless, from its inception to December 31st 1994, the results of the compensation system set up by the 1982 law have been globally positive although they have not enabled the constitution of the equalization reserves necessary to overcome a disaster of large magnitude.

From August 14, 1982 to December 31st, 1994 the amount of disaster-damage, overheads, commissions paid and reinsurance costs represent 7,8 billion dollars (39 billion francs), while the premiums collected total 8,8 billion dollars ( 44 billion francs).

\section{Conclusion}

Twelve years of experience in the new natural disaster compensation system has shown that the original system retained by the lawmaker has its merits. Its financing is largely based on the insurance system, particularly for the settlement of disasters. However, one must admit that alone insurance companies had been unable to set up such a system as they were hindered by the "counter selection" which made uninsurable most of these risks according to conventional schemes.

This notion of solidarity made the system viable by having policy-holders not or little subject to these risks, and who would not have otherwise spontaneously taken out this type of insurance, had it not been compulsory, and participated in its financing.

This fundamental consideration should prevent in future, in a concern for fairness, premiums being differentiated to take into account risks actually incurred by each person. Lightening the contribution of the majority of policy-holders who are little exposed to risks, while the contribution of the remainder, a minority, who are highly exposed to these risks, could not for obvious economic reasons be increased, would cause a serious imbalance of the system to the point of threatening its very existence.

This same notion of solidarity, however, is also an obstacle to the development of a prevention policy based on the natural disaster compensation system. This explains why prevention is the weak point of the July 13, 1982 law, and in future it will be no easy task to remedy this situation. 